University of California, Hastings College of the Law UC Hastings Scholarship Repository

Faculty Scholarship

2009

\title{
After Sosa: The Future of Customary International Law in the United States
}

William S. Dodge

UC Hastings College of the Law, dodgew@uchastings.edu

Follow this and additional works at: http://repository.uchastings.edu/faculty_scholarship

Part of the International Law Commons

\section{Recommended Citation}

William S. Dodge, After Sosa: The Future of Customary International Law in the United States, 17 Willamette J. Int'l L. \& Disp. Resol. 21 (2009).

Available at: http://repository.uchastings.edu/faculty_scholarship/107

This Article is brought to you for free and open access by UC Hastings Scholarship Repository. It has been accepted for inclusion in Faculty Scholarship by an authorized administrator of UC Hastings Scholarship Repository. For more information, please contact marcusc@uchastings.edu. 


\title{
UNIVERSITY of CALIFORNIA HASTINGS COLLEGE OF THE LAW
}

\section{Faculty Publications}

UC Hastings College of the Law Library

\author{
Author: William S. Dodge \\ Source: $\quad$ Willamette Journal of International Law and Dispute Resolution \\ Citation: $\quad 17$ Willamette J. INT'L L. \& Disp. Resol. 21 (2009). \\ Title: $\quad$ After Sosa: The Future of Customary International Law in the United States
}

Originally published in WiLLAMETTE JOURNAL OF INTERNATIONAL LAW AND DISPUTE RESOlUtiON. This article is reprinted with permission from WILLAMETTE JOURNAL OF INTERNATIONAL LAW AND DISPUTE RESOLUTION and Willamette University College of Law. 


\title{
AFTER SOSA: THE FUTURE OF CUSTOMARY INTERNATIONAL LAW IN THE UNITED STATES
}

\author{
WILLIAM S. DODGE*
}

I. Introduction 21

II. Customary International Law in Alien Tort Litigation................................22

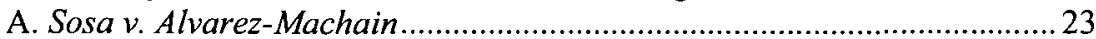

B. The Future of Alien Tort Litigation..........................................................26

III. Customary International Law as Federal Common Law............................. 28

IV. Customary International Law and the Constitution .................................. 31

A. Customary International Law and the President .................................... 34

B. Customary International Law and the Courts ........................................ 38

C. Customary International Law and the States ...................................... 42

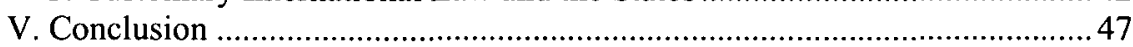

\section{INTRODUCTION}

Over the past three decades, one of the principal applications of customary international law in U.S. courts has been in human rights litigation brought under the Alien Tort Statute ("ATS"). In its current form, the statute provides: "The district courts shall have original jurisdiction of any civil action by an alien for a tort only, committed in violation of the law of nations or a treaty of the United States." The ATS is no modern innovation. It was part of the Judiciary Act of 1789 that first established the federal courts and was a response to experience under the Articles of Confederation that showed the danger of leaving redress for violations of the law of nations - the eighteenth-century name for customary international law-to the courts of the several states. ${ }^{2}$

* Professor of Law, University of California, Hastings College of the Law. An earlier version of this article was presented at the American Enterprise Institute's 2006 conference on Outsourcing American Law. Thanks to John Yoo for comments on an earlier draft.

1. 28 U.S.C. $\$ 1350(2010)$.

2. The origins of the ATS have been the subject of exhaustive historical research. See William R. Casto, The Federal Courts' Protective Jurisdiction over Torts Committed in Violation of the Law of Nations, 18 CONN. L. REV. 467 (1986); Anne-Marie Burley, The Alien Tort Statute and the Judiciary Act of 1789: A Badge of Honor, 83 AM. J. INT'L L. 461 (1989); William S. Dodge, The Historical Origins of the Alien Tort Statute: A Response to the “Originalists," 19 HASTINGS INT'L \& COMP. L. REV. 221 (1996). 
In Sosa v. Alvarez-Machain, the Supreme Court of the United States at last addressed the scope of the ATS. It held that the ATS authorizes the federal courts to apply customary international law without any further action by Congress because the provision was "enacted on the understanding that the common law would provide a cause of action for the modest number of international law violations with a potential for personal liability at the time."3 After acknowledging that the First Congress was thinking of violations of safe conducts, infringement of the rights of ambassadors, and piracy, the Court nevertheless concluded that federal courts may recognize claims "based on the present-day law of nations [that]. . . rest on a norm of international character accepted by the civilized world and defined with a specificity comparable to the features of the 18th-century paradigms we have recognized."4 In so doing, the Supreme Court reaffirmed the centuries-old principle "that the domestic law of the United States recognizes the law of nations." 5

Yet the decision in Sosa raises as many questions as it answers. Specifically, Sosa says nothing directly about the role of customary international law in the constitutional plan of the United States. Is customary international law, for example, among "the Laws" that Article II of the Constitution requires the President to "take Care . . . be faithfully executed"? Is customary international law included in the "Laws of the United States" for the purposes of federal court jurisdiction under Article III? And does customary international law bind the states under the Supremacy Clause of Article VI in the same way as federal statutes and treaties? It is to these unresolved questions, that this article is mainly addressed.

\section{CUSTOMARY INTERNATIONAL LAW IN ALIEN TORT LITIGATION}

Professor Curtis Bradley has noted that alien tort litigation has come in waves. ${ }^{6}$ The first wave began in 1980 with the Second Circuit's decision in Filartiga v. Pena-Irala, which held that the ATS gave the federal courts jurisdiction over a suit between two aliens for torture that occurred in Paraguay. ${ }^{7}$ As Professor Harold Koh has written, Filartiga

3. Sosa v. Alvarez-Machain, 542 U.S. 692, 724 (2004).

4. Id. at 725 .

5. Id. at 729 .

6. Curtis A. Bradley, Customary International Law and Private Rights of Action, $1 \mathrm{CHI}$. J. INT'L L. 421, 421 (2000).

7. Filartiga v. Pena-Irala, 630 F.2d 876 (2d Cir. 1980). 
was the Brown v. Board of Education of international human rights, ${ }^{8}$ and a series of similar suits soon followed. These first-wave suits share certain characteristics: they are disputes between two aliens; they allege grave violations of human rights such as torture, extrajudicial killing, genocide, and war crimes; and they involve violations that occurred abroad.

A second wave of alien tort suits began in the 1990s. In these suits, the defendants are corporations-usually U.S. corporations. Although these suits sometimes allege violations of human rights by the defendants themselves, they often proceed on a theory of vicarious liability, seeking to hold corporations liable for "aiding and abetting" the acts of foreign governments. A famous example is Doe $v$. Unocal, in which a class of Burmese villagers brought suit alleging that Unocal had aided and abetted the Burmese military's program of forced labor for the construction of a pipeline. ${ }^{9}$

The third wave of alien tort suits involves claims against U.S. government officials and others working on behalf of the U.S. government. Although some such suits were filed as early as the 1980s, this wave has swelled with cases arising from the war in Iraq and U.S. anti-terrorism policies. ${ }^{10}$

\section{A. Sosa v. Alvarez-Machain}

Sosa v. Alvarez-Machain was one of these third-wave cases. It began in 1990 when Dr. Humberto Alvarez-Machain was indicted in the United States for his alleged participation in the torture and murder of a DEA agent in Mexico. When Mexico refused to extradite Alvarez, the DEA came up with a plan to abduct him and bring him to the United States for trial, which was accomplished with the help of a group of Mexicans including Jose Sosa. Alvarez moved to dismiss the indictment because of the DEA's conduct, but the Supreme Court held that his abduction did not affect the jurisdiction of the district court. ${ }^{1}$ At trial, the district court granted Alvarez's motion for a judgment of acquittal at the close of the government's case. Alvarez then sued the United States under the Federal Tort Claims Act and his Mexican abductors under the

8. Harold Hongju Koh, Transnational Public Law Litigation, 100 YALE L.J. 2347, 2366 (1991).

9. Doe v. Unocal Corp., 110 F. Supp. 2d 1294 (C.D. Cal. 2000), vacated, 403 F.3d 708 (9th Cir. 2005).

10. See Julian G. Ku, The Third Wave: The Alien Tort Statute and the War on Terrorism, 19 EMORY INT'L L. REV. 105 (2005).

11. United States v. Alvarez-Machain, 504 U.S. 655 (1992). 
ATS. The district court awarded $\$ 25,000$ in damages against Sosa, and the Ninth Circuit affirmed. ${ }^{12}$

Although the case arose long before September 11, 2001, it was fraught with implications for the "war on terror," for it raised the possibility that U.S. officials or others who might aid them in capturing and detaining foreign suspects could be subject to civil liability for violating customary international law. It was this aspect of the case that made Sosa an attractive one for the Bush Administration to take to the Supreme Court, and a frightening one for supporters of the first-wave suits like Filartiga. But considerations from the second wave of corporate cases critically affected decisions by Sosa's counsel and the Bush Administration about which arguments to press before the Court.

Sosa's principal argument to the Supreme Court was that no suit could be brought under the Alien Tort Statute unless Congress had granted an express cause of action. This "cause of action" argument came from Judge Bork's concurring opinion in a 1984 case called TelOren v. Libyan Arab Republic. ${ }^{13}$ Judge Bork had written that the ATS was purely jurisdictional and that further action by Congress was necessary to create a right to sue for violations of customary international law. In 1992, Congress passed such statute-the Torture Victim Protection $\mathrm{Act}^{14}$-but it provided an express cause of action only for claims of torture and extrajudicial killing against individuals. Since corporations are probably not "individuals" within the meaning of the TVPA, success on the "cause of action" argument would have eliminated at one stroke the second-wave cases, as well as any first- or third-wave cases founded on claims other than torture or extrajudicial killing.

Neither Sosa's counsel nor the Bush Administration chose to make the alternative argument that alien tort suits between aliens were unconstitutional because they exceeded the limits of Article III's grant of subject-matter jurisdiction to the federal courts, an argument ably sketched in a 2002 article by Professor Bradley. ${ }^{15}$ If successful, this argument would have barred the suit in Sosa and other third-wave cases involving foreign defendants. It would also have barred first-wave cases

12. Alvarez-Machain v. United States, 331 F.3d 604 (9th Cir. 2003) (en banc).

13. 726 F.2d 774, 798-823 (D.C. Cir. 1984) (Bork, J., concurring).

14. Pub. L. No. 102-256, 106 Stat. 73 (1992) (codified at 28 U.S.C. $\$ 1350$ note).

15. Curtis A. Bradley, The Alien Tort Statute and Article III, 42 VA. J. INT'L L. 587 (2002). It is possible that the district court might have had supplemental jurisdiction over Alvarez's claim against Sosa under 28 U.S.C. $\$ 1367$ (a) because of Alvarez's federal claim against the United States under the Federal Tort Claims Act, but supplemental jurisdiction does not seem to have been argued. See William A. Fletcher, International Human Rights in American Courts, 93 VA. L. REv. 653, 665 n.61 (2007). 
between aliens like Filartiga. But it would not have stopped the secondwave cases against American corporations because Article III of the Constitution expressly provides for jurisdiction over "Controversies . . . between ... the Citizens [of a State], and foreign ... Citizens or Subjects."

Sosa thus became a stalking horse for the corporate cases. The $\$ 25,000$ in damages awarded against Sosa hardly justified taking the case to the Supreme Court, but Sosa's counsel was also counsel to Unocal. The Bush Administration had supported the "cause of action" argument with an amicus brief in Unocal and saw Sosa as a good vehicle to present that argument to the Supreme Court.

This strategic choice proved a poor one for opponents of the ATS, because in choosing the argument with the broadest impact they also chose the one with the weakest historical basis. It is clear beyond doubt that in 1789 , when the ATS was passed as part of the First Judiciary Act, the law of nations was considered part of the general common law. ${ }^{16}$ No express cause of action was needed because the common law provided a right of action for "torts in violation of the law of nations" just as it provided a right of action for other torts. The Supreme Court thus rejected the "cause of action" argument in Sosa, and in a part of the opinion joined by all nine justices held that the ATS "is best read as having been enacted on the understanding that the common law would provide a cause of action for the modest number of international law violations with a potential for personal liability at the time."17

Justice Souter's opinion went on to hold that suits could be brought under the act not just for violations of safe conducts, infringement of the rights of ambassadors, and piracy, but also for violations of "the present-day law of nations" that "rest on a norm of international character accepted by the civilized world and defined with a specificity comparable to the features of the 18th-century paradigms we have recognized." 18 At this point, Souter lost three votes. Justice Scalia's

16. See Curtis A. Bradley \& Jack L. Goldsmith, Customary International Law as Federal Common Law: A Critique of the Modern Position, 110 HARV. L. REV. 815, 824 (1997); Koh, supra note 8, at 2354; Stewart Jay, The Status of the Law of Nations in Early American Law, 42 VAND. L. REV. 819, 832-33 (1989); William A. Fletcher, The General Common Law and Section 34 of the Judiciary Act of 1789: The Example of Marine Insurance, 97 HARV. L. REV. 1513, 1517 (1984); Louis Henkin, International Law as Law in the United States, $82 \mathrm{MICH}$. L. REV. 1555, 1557 (1984).

17. Sosa v. Alvarez-Machain, 542 U.S. 692, 724 (2004). I disclose that I wrote the amicus brief of Professors of Federal Jurisdiction and Legal History urging the position the Supreme Court adopted. See id. at 714.

18. Id. at 725 . 
concurring opinion, joined by Chief Justice Rehnquist and Justice Thomas, argued that the Court's rejection of a "general federal common law" in the 1938 case Erie Railroad v. Tompkins had closed the door to ATS suits based on modern international law. ${ }^{19}$ Scalia's opinion drew heavily on a 1997 Harvard Law Review article by Professors Curtis Bradley and Jack Goldsmith arguing that after Erie federal courts should treat customary international law as state, rather than federal, common law. ${ }^{20}$ The majority, however, rejected the Bradley-Goldsmith position, expressly characterizing modern customary international law as "federal common law," 21 at least for purposes of the ATS.

\section{B. The Future of Alien Tort Litigation}

The effect of Sosa was to endorse the status quo in alien tort litigation. Although the Court reversed the award of damages, holding that Alvarez-Machain's brief detention violated no well-established norm of customary international law, ${ }^{22}$ the standard it adopted for general acceptance and specificity was in substance the same one that lower courts had been applying in the first-wave cases. Indeed, the Court stated that its standard was "generally consistent" with lower-court decisions, citing several with approval including Filartiga. ${ }^{23}$ It seems clear, then, that the first-wave of alien torts suits between aliens for grave violations of human rights abroad will continue in U.S. courts.

The prognosis for the second-wave suits against corporations is still uncertain. The Second Circuit has gone furthest in attempting to rein in such suits after Sosa. ${ }^{24}$ In Presbyterian Church of Sudan v. Talisman Energy, Inc., the Second Circuit held that a defendant could not be held liable for aiding and abetting unless it acted with the purpose of facilitating violations of international law. ${ }^{25}$ Then, in Kiobel v. Royal Dutch Shell Petroleum Co., the Second Circuit held that corporations could not be held liable under the ATS at all. ${ }^{26}$ The Eleventh Circuit has

\footnotetext{
19. Id. at 746 (Scalia, J. concurring).

20. See Bradley \& Goldsmith, supra note 16 , at 870 .

21. Sosa, 542 U.S. at 732 .

22. Id. at 738 .

23. Id. at 732 .

24. Sosa did not address the corporate cases directly. In one footnote, the Court noted that if the defendant were a private actor like a corporation, the question would arise whether international law applied. 542 U.S. at 732 n.20. In another footnote, the Court referred to cases filed against corporations that did business in South Africa under apartheid, suggesting that the federal courts might properly defer to the political branches if the executive filed a case-
} specific objection based on foreign policy. Id. at $733 \mathrm{n} .21$.

25. See 582 F.3d 244, 259 (2d Cir. 2009), cert. denied, 2010 WL 1607314 (Oct. 4, 2010 ).

26. See 62I F.3d 111, 145 (2d Cir. 2010). 
disagreed on both points, holding that "corporate defendants are subject to liability under the ATS"27 and that knowledge is enough for aiding and abetting liability. ${ }^{28}$ At the moment, the Supreme Court is not disposed to intervene. It denied petitions for certiorari in Talisman raising both issues. ${ }^{29}$

As a historical matter it is clear that the ATS was meant to apply to violations of the law of nations by private parties even if they were not acting under color of state law. Each of the three eighteenth-century paradigms the First Congress had in mind-violations of safe conducts, infringement of the rights of ambassadors, and piracy-involved precisely that kind of situation. It is also clear that in the eighteenth century those who aided and abetted violations of the law of nations could be held liable. In his discussion of offenses against the law of nations, William Blackstone noted that, both at common law and by statute, accessories to piracy were subject to punishment by death like principals. ${ }^{30}$ President Washington's 1793 Neutrality Proclamation threatened punishment under the law of nations not just for those who committed hostilities against other nations but also for those "aiding and abetting hostilities against any of the said powers." 31 Finally, liability for violations of the law of nations was not limited to natural persons during the late eighteenth and early nineteenth centuries, ${ }^{32}$ and the text of the ATS imposes no such limitation. ${ }^{33}$

At first, Sosa appeared to give a boost to the third-wave suits. Although the Court held that "a single illegal detention of less than a day, followed by the transfer of custody to lawful authorities and a prompt arraignment" was not actionable, ${ }^{34}$ the Bush Administration's antiterrorism policies hardly fit that description. Many of the third-wave cases involved allege violations like torture that clearly meet the Sosa

27. Sinaltrainal v. Coca-Cola Co., 578 F.3d 1252, 1263 (11 th Cir. 2009).

28. See Cabello v. Fernandez-Larios, 402 F.3d 1148, 1159 (11 th Cir. 2005)

29. See Presbyterian Church of Sudan v. Talisman Energy, Inc., 2010 WL 1607314 (Oct. 4, 2010); Talisman Energy, Inc. v. Presbyterian Church of Sudan, 2010 WL 2033143 (Oct. 4, 2010).

30. 4 William Blackstone, Commentaries *66, *72.

31. GeORge Washington, Proclamation of NeUtrality (Apr. 22, 1793), reprinted in 32 THE Writings of GEORGE WASHINGTON FROM THE ORIGINAL MANUSCRIPT SOURCES, 1745-1799, at 430-31 (J.C. Fitzpatrick ed., 1939).

32. See The Marianna Flora, 24 U.S. (11 Wheat.) 1, 40-41 (1825) ("a piratical aggression by an armed vessel sailing under the regular flag of any nation, may be justly subjected to the penalty of confiscation for such a gross breach of the law of nations").

33. The ATS requires that the plaintiff be an alien but imposes no limitations on who may be a proper defendant. See supra note 2 and accompanying text.

34. Sosa v. Alvarez-Machain, 542 U.S. 692, 738 (2004). 
standard. And the day before Sosa came down, the Court made a point of noting in Rasul v. Bush that prisoners in detention could still bring alien tort claims. ${ }^{35}$ But these suits met with little success after Sosa. In 2006 Congress prohibited all suits by aliens detained as enemy combatants, ${ }^{36}$ and other claims have been barred under the Westfall Act. ${ }^{37}$

But beyond its direct impact on alien tort litigation, the Sosa decision speaks more generally to the place of customary international law in the U.S. legal system. It holds that customary international law may be applied as federal common law even if not expressly incorporated by Congress. Moreover, Sosa's approach allows us to address other questions that the decision itself left open-questions concerning the place of customary international law in our constitutional scheme.

\section{CUSTOMARY INTERNATIONAL LAW AS FEDERAL COMMON LAW}

Sosa directly answers one question that has caused a good deal of academic controversy-whether customary international law is federal common law or state common law. While this controversy might seem like a technical one of interest only to law professors, it has important implications. If customary international law were state common law, then federal courts would not be able to apply it in ATS cases or others unless it had been adopted by the courts of the state whose law applied. Each state would also be free to interpret customary international law in its own way, and federal courts would be bound to follow those interpretations. If, on the other hand, customary international law were federal common law, then all courts-federal and state - would be bound by uniform rules. Federal courts would be free to apply those rules irrespective of what the states had done and indeed irrespective of whether Congress had incorporated customary international law by statute, so long as they had jurisdiction over the particular case.

The question is a modern one. At the time of the Framing, the law of nations was neither federal nor state common law. Those categories did not exist. Rather, the law of nations was understood to be part of the

35. Rasul v. Bush, 542 U.S. 466,485 (2004).

36. See Military Commissions Act of 2006, Pub. L. No. 109-366, $\S 7(a), 120$ Stat. 2600, 2635-36 (2006), (codified as amended at 28 U.S.C. $\S 2241(\mathrm{e})(2))$. The Supreme Court's decision in Boumediene v. Bush, 128 S. Ct. 2229 (2008), held this unconstitutional only with respect to petitions for habeas corpus.

37. See Karen Lin, An Unintended Double Standard of Liability: The Effect of the Westfall Act on the Alien Tort Claims Act, 108 CoLUM. L. REv. 1718 (2008). 
general common law, which was binding on both federal and state courts alike without any need for legislative incorporation. As Attorney General Edmund Randolph noted in an early legal opinion for Secretary of State Thomas Jefferson, "[t]he law of nations, although not specially adopted by the constitution or any municipal act, is essentially a part of the law of the land." 38

In 1938 the Supreme Court put an end to the regime of general common law in Erie Railroad v. Tompkins ${ }^{39}$ and substituted a system in which the common law was generally state law, with small pockets of federal common law. Erie raised the question of where customary international law fit into the new system.

Not long after Erie, Professor Philip Jessup argued that customary international law should be treated as federal common law. "Any question of applying international law in our courts," he wrote, "involves the foreign relations of the United States and can thus be brought within a federal power. . . It would be as unsound as it would be unwise to make our state courts our ultimate authority for pronouncing the rules of international law. ${ }^{, 40}$ Twenty-five years later, in Banco Nacional de Cuba v. Sabbatino, the Supreme Court seemed to endorse Jessup's argument "that rules of international law should not be left to divergent and perhaps parochial state interpretations," reasoning further that "[h]is basic rationale is equally applicable to the act of state doctrine." the orthodox view, as summarized in the Restatement (Third) of Foreign Relations Law, has been that "[c]ustomary international law is considered to be like common law in the United States, but it is federal law." 42

This view was not without its critics, however, and prominent among them were Professors Bradley and Goldsmith, whose 1997 article in the Harvard Law Review argued that federal courts could not apply customary international law after Erie without some domestic authorization to do so. Early decisions applying the law of nations as general common law provided no authority to apply customary international law as federal common law. Since there was also no authorization in the U.S. Constitution or in federal statutes, they argued, federal courts could apply customary international law only if it had been

38. I Op. Att'y Gen. 26, 27 (1792).

39. See Erie R.R. v. Tompkins, 304 U.S. 64 (1938).

40. Philip C. Jessup, The Doctrine of Erie Railroad v. Tompkins Applied to International Law, 33 AM. J. INT'L L. 740, 743 (1939).

41. Banco Nacional de Cuba v. Sabbatino, 376 U.S. 398, 425 (1964).

42. RESTATEMENT (THIRD) OF FOREIGN RELATIONS LAW $\S 111 \mathrm{cmt}$. d (1987). 
incorporated into state law. ${ }^{43}$ Although Bradley and Goldsmith refer to the view that customary international law is federal common law as the "modern position," 44 it is worth noting that their own view that customary international law should be considered state common law is equally modern. Both views try to fit customary international law into a post-Erie framework that is far removed from the original understanding.

The Sosa decision speaks directly to this controversy. Sosa's lawyers and the Bush Administration argued that federal courts could not apply customary international law in alien tort cases without further authorization from Congress in the form of an express cause of action. In his concurring opinion, Justice Scalia agreed. With respect to the federal courts' power to apply customary international law as federal common law, he followed the basic outlines that Bradley and Goldsmith set down. "Because post-Erie federal common law is made, not discovered," Scalia wrote, "federal courts must possess some federal-common-law-making authority before undertaking to craft it." ${ }^{45}$ Neither pre-Erie decisions applying the law of nations nor the ATS provided such authority. "PostErie federal common lawmaking ... is so far removed from that generalcommon-law adjudication which applied the 'law of nations' that it would be anachronistic to find authorization to do the former in a statutory grant of jurisdiction that was thought to enable the latter.",46

The Sosa majority, however, rejected the argument that Erie had "close[d] the door" ${ }^{\prime \prime 7}$ on the federal courts' ability to apply customary international law as common law. "Erie did not in terms bar any judicial recognition of new substantive rules, no matter what the circumstances," the Court wrote, "and post-Erie understanding has identified limited enclaves in which federal courts may derive some substantive law in a common law way. For two centuries we have affirmed that the domestic law of the United States recognizes the law of nations." ${ }^{48}$ The majority stressed continuity and its desire to do justice to the original understanding of the ATS, noting that "it would be unreasonable to assume that the First Congress would have expected federal courts to lose all capacity to recognize enforceable international norms simply because the common law might lose some metaphysical cachet on the

43. Bradley \& Goldsmith, supra note 16 , at 870 .

44. Id. at 816 .

45. Sosa v. Alvarez-Machain, 542 U.S. 692, 741 (2004) (Scalia, J., concurring).

46. Id. at 745 (Scalia, J., concurring).

47. Id. at 729 .

48. Id. 
road to modern realism." ${ }^{49}$ And lest there be any doubt about how claims under customary international law fit into the post-Erie world, the Court expressly characterized such claims as "claims under federal common law." 50

\section{CUSTOMARY INTERNATIONAL LAW AND THE CONSTITUTION}

While settling some questions about the place of customary international law in the U.S. legal system, the Sosa decision left open a number of others. To illustrate, it is useful to look at an exchange of footnotes between Justice Scalia and the majority. In a footnote to his concurring opinion, Scalia argued that if customary international law were federal common law for ATS purposes it would be federal common law for all purposes. Thus, it would bind the states under the Supremacy Clause of Article VI and would serve as the basis for "arising under" jurisdiction both for the purposes of Article III and for the purposes of the general federal question statute. ${ }^{51}$ If the general federal question statute reached violations of customary international law, then any such violation could be brought in federal court without regard to the limitations imposed by the ATS that the plaintiff be an alien and that the suit sound in tort.

The majority responded with a footnote of its own. It denied that cases involving customary international law would fall within the general federal question statute. The ATS, it noted, "was enacted on the congressional understanding that courts would exercise jurisdiction by entertaining some common law claims derived from the law of nations; and we know of no reason to think that federal-question jurisdiction was extended subject to any comparable congressional assumption." 52 But

49. Id. at 730 .

50. Id. at 732. Professors Bradley and Goldsmith have tried to salvage what they can of their position, claiming that Sosa actually supports their argument that "courts can domesticate CIL [customary international law] only in accordance with the requirements and limitations of post-Erie federal common law." Curtis A. Bradley, Jack L. Goldsmith \& David H. Moore, Sosa, Customary International Law, and the Continuing Relevance of Erie, 120 HARV. L. REV. 869,874 (2007). The latest version of the Bradley-Goldsmith thesis misreads Sosa, is contrary to the original understanding, and fails Erie's own test of legitimacy. See William S. Dodge, Customary International Law and the Question of Legitimacy, 120 HARV. L. REV. F. 19 (2007).

51. Sosa, 542 U.S. at 745 n.* (Scalia, J., concurring).

52. Id. at $731 \mathrm{n} .19$. For an argument that the Court was wrong and that Congress did expect at least some cases arising under the law of nations to fall within the general federal question statute, see Gwynne Skinner, Federal Jurisdiction over U.S. Citizens' Claims for Violations of the Law of Nations in Light of Sosa, 37 GA. J. INT'L COMP. L. 53 (2008). 
the majority refused to be drawn on the constitutional questions, leaving those issues for another day.

So how does customary international law fit into the Constitution of the United States? Is it binding on the states under the Supremacy Clause of Article VI? Is it part of the "Laws of the United States" over which Article III gives the federal courts jurisdiction? Or for that matter, is it part of "the Laws" that Article II requires the President to "take Care . . . be faithfully executed"' ${ }^{53}$ Sosa does not answer these questions, but it does provide a method that may be used to analyze them.

Sosa's method is both particularized and evolutionary. ${ }^{54}$ It is particularized in that it rejects the all-or-nothing approach of Justice Scalia and many legal scholars that treats customary international law as federal common law either for all purposes or for none. Instead, as illustrated in its different treatment of the ATS and the general federal question statute, Sosa's method proceeds statute by statute and constitutional provision by constitutional provision. This makes good sense because, as we shall see, the text and history of each provision are different. To illustrate briefly, Article II of the Constitution refers broadly to "the Laws" that the President shall take care be faithfully executed. Article III uses a narrower phrase "the Laws of the United States" in describing the jurisdiction of the federal courts, while the Supremacy Clause of Article VI refers even more narrowly to "the Laws of the United States which shall be made in Pursuance [of this Constitution]." As a simple matter of interpretation, different phrases in the same document should generally be interpreted to mean different things. To conflate them, as Justice Scalia's concurring opinion in Sosa does, is to violate the most basic rules of constitutional interpretation.

Sosa's method is evolutionary in that it begins with text and history but does not end there. The Sosa Court devoted a good deal of attention to the original understanding of the ATS, but it went on to consider modern developments that "argue for judicial caution when considering the kinds of individual claims that might implement the jurisdiction conferred by the early statute." 55 In the context of the ATS, the Court noted five reasons for caution. First, the prevailing conception of the common law had changed, so that today "there is a general understanding that the law is not so much found or discovered as it is

53. See Michael D. Ramsey, The Constitution's TeXt In Foreign AfFairs (2007) for an excellent discussion of these questions and others from a textualist viewpoint.

54. See William S. Dodge, Bridging Erie: Customary International Law in the U.S. Legal System After Sosa v. Alvarez-Machain, 12 TULSA J. COMP. \& INT'L L. 87, 96-100 (2004).

55. Sosa, 542 U.S. at 725. 
either made or created." 56 Second, the role of the federal courts in making common law changed with Erie, which prohibited them from making common law generally and confined them "to havens of specialty." 57 Third, the modern view is that "the decision to create a private right of action is one better left to legislative judgment in the great majority of cases." 58 Fourth were the potential implications for the foreign relations of the United States:

It is one thing for American courts to enforce constitutional limits on our own State and Federal Governments' power, but quite another to consider suits under rules that would go so far as to claim a limit on the power of foreign governments over their own citizens, and to hold that a foreign government or its agent has transgressed those limits. . . .Yet modern international law is very much concerned with just such questions .... ${ }^{59}$

Fifth, and finally, Congress had given the federal courts no "mandate to seek out and define new and debatable violations of the law of nations." 60

The Sosa Court's evolutionary approach of considering not just the original understanding but also modern developments makes good sense. There have been enormous changes in both international law and in the domestic legal system over the past two hundred and twenty years. $^{61}$ To list just the three most significant, the understanding of customary international law changed dramatically during the nineteenth century from a foundation of natural law to positivism based on state practice and consent; ${ }^{62}$ the place of customary international law in the U.S. legal order changed in the early twentieth century when Erie abolished the general common law and replaced it with the categories of state and federal common law; ${ }^{63}$ and the roles of our branches of government in making and interpreting customary international shifted with the rise of positivism during the nineteenth century and with the

56. Id.

57. Id. at 726

58. Id. at 727

59. Id.

60. Id. at 728 .

61. See generally INTERNATIONAL LAW IN THE U.S. SUPREME COURT: CONTINUITY AND CHANGE (David L. Sloss, Michael D. Ramsey \& William S. Dodge eds., forthcoming 2011).

62. See William S. Dodge, The Paquete Habana: Customary International Law as Part of Our Law, in INTERNATIONAL LAW STORIES 175, at 187-89 (John E. Noyes, Laura A. Dickinson \& Mark W. Janis eds., 2007); ARTHUR NUSSBAUM, A CONCISE HISTORY OF THE LAW OF NATIONS 222-25 (1947); Edwin D. Dickinson, Changing Concepts and the Doctrine of Incorporation, 26 AM. J. INT'L L. 239, 252-60 (1932).

63. See Erie R.R. v. Tompkins, 304 U.S. 64 (1938). 
ascendancy of the President in foreign affairs during the twentieth. ${ }^{64}$ In short, in the area of international law it is not possible to be a strict originalist because the Framers' world no longer exists. One must necessarily translate the original understandings into modern terms.

Let us turn then to apply Sosa's particularized, evolutionary method to three constitutional questions: whether customary international law binds the President under Article II; whether Article III gives the federal courts jurisdiction over suits arising under it; and whether it binds the states under the Supremacy Clause of Article VI.

\section{A. Customary International Law and the President}

Article II of the Constitution requires that the President "take Care that the Laws be faithfully executed." If the law of nations is among "the Laws" referenced in Article II, then the text of the "Take Care" Clause would seem to impose upon the President a constitutional duty to obey customary international law.

Certainly that was the original understanding. The issue arose shortly after ratification in the context of the neutrality debate. The United States had entered a Treaty of Alliance with France in 1788. Following the French Revolution of 1789, France became embroiled in wars with a number of European powers, finally declaring war on England early in 1793. Although popular feelings favored France, the Washington Administration judged it in America's interests to remain neutral in these conflicts, and on April 22 President Washington issued a Proclamation of Neutrality. The Proclamation promised "a conduct friendly and impartial towards the belligerent powers." U.S. citizens were warned that if they violated "the law of nations, by committing, aiding or abetting hostilities against any of the said powers" they would not receive the protection of the United States and would be prosecuted for their violations. ${ }^{65}$

To counter objections to the Proclamation, Alexander Hamilton, wrote a series of essays under the name "Pacificus." Hamilton argued for complete presidential control over foreign affairs as an incident of executive power, save only in those instances, such as making treaties and declaring war, where the Constitution expressly gave authority to one or both houses of Congress. (And even these exceptions, he argued, "are to be construed strictly." ${ }^{\text {"6 }}$ ) As a constitutional source of authority,

64. See G. Edward White, The Transformation of the Constitutional Regime of Foreign Relations, 85 VA. L. REV. 1 (1999).

65. PROClamation of NeUTRALITY, supra note 31.

66. Pacificus No. I (June 29, 1793), reprinted in 15 THE PAPERS OF AlEXANDER 
Hamilton relied in part on the "Take Care" Clause. "The Executive is charged with the execution of all laws, the laws of Nations as well as the Municipal law, which recognizes and adopts those laws," Hamilton wrote. "It is consequently bound, by faithfully executing the laws of neutrality, when that is the state of the Nation, to avoid giving a cause of war to foreign Powers." 67 In Hamilton's view, the law of nations was part of "the Laws" under the "Take Care" Clause, and the President was "consequently bound" to observe it.

Under pressure from Thomas Jefferson, James Madison took up his pen to respond. Writing under the name "Helvidius," Madison argued that the nature of the executive power was to execute existing laws, and that the powers over war and treaties were properly legislative. ${ }^{68}$ In his second essay, Madison dissected Hamilton's paragraph, quoted above, relying on the "Take Care" Clause. That the executive was charged with the execution of all laws including the law of nations, Madison declared to be "a truth." Madison then misread Hamilton (perhaps deliberately) as suggesting that the executive was bound to execute the law of nations only to avoid giving cause of war to foreign powers. In response to this straw man, Madison emphasized that the executive was bound by the law of nations, irrespective of whether other nations would take offense, simply because it was part of the laws: "It is bound to the faithful execution of these [laws of neutrality] as of all other laws internal and external, by the nature of its trust and the sanction of its oath."69

Hamilton's and Madison's agreement about the "Take Care" Clause in the neutrality debate is striking for it was virtually the only thing about which they agreed. By 1793, these former allies and coauthors (with John Jay) of The Federalist had come to disagree about almost everything. Hamilton took a broad view of executive power; Madison a narrow one. Yet "Pacificus" and "Helvidius" did agree on this: the law of nations was part of "the Laws" under Article II and the President was "bound" by it.

For the courts, a key question was whether the President has authority to supersede customary international law as a rule of decision.

Hamilton 33, 42 (Harold C. Syrett ed., 1969).

67. Id. at 40; see also id. at 43 ("The President is the constitutional EXECUTOR of the laws. Our Treaties and the laws of Nations form a part of the law of the land.")

68. "Helvidius" Number 1 (Aug. 24, 1793), reprinted in 15 THE PAPERS OF JAMES MADISON 66, 67-72 (Thomas A. Mason et al. eds., 1985) [hereinafter MADISON PAPERS]. Helvidius Priscus was a first-century Roman opponent of imperial rule, who was executed by the Emperor Vespasian.

69. "Helvidius" Number 2 (Aug. 31, 1793), reprinted in 15 MADISON PAPERS, supra note 68 , at 86 . 
The Marshall Court repeatedly acknowledged that Congress possesses such authority. The Court did so implicitly in cases like Talbot $v$. Seeman and The Charming Betsy, ${ }^{70}$ and explicitly in The Nereide where Marshall wrote that "[t]ill such an act be passed, the Court is bound by the law of nations which is a part of the law of the land."71 This line from The Nereide at least suggested that the President lacks a similar power, for the President cannot pass an act by himself.

The Supreme Court's decision in Brown v. United States ${ }^{72}$ is sometimes cited as authority for the President to disregard customary international law. ${ }^{73}$ Referring to the law of nations in general and to the law of war specifically, Chief Justice Marshall wrote:

This usage is a guide which the sovereign follows or abandons at his will. The rule, like other precepts of morality, of humanity, and even of wisdom, is addressed to the judgment of the sovereign; and although it cannot be disregarded by him without obloquy, yet it may be disregarded. ${ }^{74}$

The words "his" and "him" seem to refer to a single person, and out of context the passage appears to support a presidential power to violate customary international law. In context, however, it is clear that Marshall was speaking of sovereigns in general, most of whom happened to be kings and therefore "hims." It is equally clear that with respect to the United States, Marshall viewed "the sovereign" not as the President alone, but as Congress and the President acting together through the legislative process. The whole question in Brown was whether the executive branch could exercise the right of the United States under the law of nations to condemn enemy property during the War of 1812 without express authorization from Congress. Writing for the Court, Marshall held that it could not. "That war gives to the sovereign full right to take the persons and confiscate the property of the enemy wherever found, is conceded." 75 Yet even a declaration of war did not vest that sovereign right in the executive. "[T]he power of

70. Talbot v. Seeman, 5 U.S. (1 Cranch) 1, 43 (1801) ("the laws of the United States ought not, if it be avoidable, so to be construed as to infract the common principles and usages of nations"); Murray v. The Schooner Charming Betsy, 6 U.S. (2 Cranch) 64, 118 (1804) ("an act of Congress ought never to be construed to violate the law of nations if any other possible construction remains").

71. The Nereide, 13 U.S. (9 Cranch) 388,423 (1815).

72. Brown v. United States, 12 U.S. (8 Cranch) 110 (1814).

73. See generally Michelle Akerman, Brown v. United States, The Paquete Habana, and the Executive, 60 HASTINGS L.J. 149 (2008).

74. Brown, 12 U.S. (8 Cranch) at 128.

75. Id. at 122 . 
confiscating enemy property is in the legislature," Marshall concluded, and "the legislature has not yet declared its will to confiscate property which was within our territory at the declaration of war." ${ }^{76}$ If the executive lacked even the power to exercise the United States' rights under the law of nations, it certainly lacked the power to violate that law.

The point becomes clear beyond dispute when one reads the dissenting opinion of Justice Story. Story thought that the declaration of war in 1812 was enough to enable the executive to seize British property. But even he-the strongest advocate of executive power in this case-was absolutely certain that the President could not violate the law of nations. The President, Story wrote, "cannot lawfully transcend the rules of warfare established among civilized nations[.] He cannot lawfully exercise powers or authorize proceedings which the civilized world repudiates and disclaims."

The view that the President could not violate customary international law persisted throughout the nineteenth century, even with the rise of positivism. Advocates of presidential power sometimes cite the Supreme Court's statement in the 1900 case The Paquete Habana that "where there is no treaty and no controlling executive or legislative act or judicial decision, resort must be had to the customs and usages of civilized nations." 78 They argue that the reference to a "controlling executive . . . act" recognizes a presidential authority to supersede customary international law. This passage is at best ambiguous, however, since executive acts are placed on a par both with legislative acts, which clearly could violate customary international law, and with judicial decisions, which clearly could not. It is also dictum, unnecessary to the Court's decision. Indeed the Court went to great lengths to note that the policy of the executive branch with respect to its blockade of Cuba during the Spanish-American War was to observe and respect customary international law. More probative are the legal briefs that the Department of Justice submitted to the Supreme Court, in which the Department argued at great length about the content of the international law rules governing the capture of enemy ships as prizes of war but never once asserted that the President or his subordinates had authority to violate those rules. ${ }^{79}$ And most conclusively, of course, the Supreme Court ruled

76. Id. at 129 .

77. Id. at 153 (Story, J., dissenting).

78. The Paquete Habana, 175 U.S. 677, 700 (1900). For discussion of this case, see Dodge, supra note 62.

79. See Jordan J. Paust, Paquete and the President: Rediscovering the Brief for the United 
against the executive branch in The Paquete Habana, holding it liable under customary international law for capturing a coastal fishing vessel in violation of that law.

The proposition that the executive acting by itself might have authority to violate customary international law only became tenable in the twentieth century as the Supreme Court began to view the President as "the sole organ of the federal government in the field of international relations." ${ }^{80}$ Today, such authority is sometimes claimed to be a functional necessity. The example frequently given is President Truman's 1945 proclamation asserting a new right over the resources of the continental shelf contiguous to the coasts of the United States. This proclamation arguably violated existing customary international law, but was soon followed by other coastal states, and a new rule of customary international law emerged. If states cannot violate customary international law, state practice cannot change and the rules of customary international law cannot develop. And if the United States cannot violate customary international law, it cannot participate in the development of these new rules. ${ }^{81}$

One may concede the necessity for the United States to be able, on occasion, to violate customary international law without taking the extreme position that the President acting alone has the authority to place the United States in violation of those rules. As we have seen, the original understanding was that the President was bound by customary international law. It may be that the modern world requires a departure from the original understanding, but the burden should be on those arguing for the departure to prove its necessity.

\section{B. Customary International Law and the Courts}

While state courts may hear any case in which they have jurisdiction over the parties, federal courts are limited by Article III of the Constitution to hearing only certain categories of cases. Congress can choose to withhold some of this jurisdiction from the federal courts, but it cannot give them a broader jurisdiction than the Constitution allows. Article III allows federal jurisdiction over cases "arising under this

States, 34 VA. J. INT'L L. 981 (1994). The United States did not even argue for deference to the executive's interpretation of customary international law. See Dodge, supra note 62, at 181 n.50.

80. United States v. Curtiss-Wright Export Corp., 299 U.S. 304, 320 (1936). See generally White, supra note 64.

81. See Jonathan I. Charney, The Power of the Executive Branch of the United States Government to Violate Customary International Law, 80 AM. J. INT'L L. 913 (1986). 
Constitution, the Laws of the United States, and Treaties made, or which shall be made, under their Authority." The failure to mention cases arising under the law of nations explicitly has led some to argue that the federal courts have no jurisdiction to hear such cases unless jurisdiction may be found under one of Article III's other heads of jurisdiction, which include suits between an alien and a citizen of one of the United States, but not suits between two aliens. ${ }^{82}$ If this is correct, then the Alien Tort Statute is unconstitutional as applied to suits between two aliens-suits like Filartiga and Sosa. Although Sosa's counsel chose not to raise this argument before the Supreme Court for reasons that have already been mentioned, it remains a threat to future ATS plaintiffs, particularly in first-wave suits.

Of course, it would have been unnecessary for Article III to mention the law of nations expressly if that body of law was understood to be part of "the Laws of the United States," and (as I have argued at length elsewhere) that was indeed the original understanding. ${ }^{83}$ One may begin by comparing Article III's phrase to those found in Articles II and VI. Although "the Laws of the United States" seems narrower than Article II's unqualified reference to "the Laws," it is also undoubtedly broader than the corresponding phrase in Article VI- "Laws of the United States which shall be made in Pursuance [of this Constitution]." The difference with Article VI suggests that there is at least one category of laws not made through the legislative process set out in Article I of the Constitution that are still "Laws of the United States" for the purpose of Article III. Historical evidence confirms that the law of nations was just such a category.

One of the principal shortcomings of the Articles of Confederation was that the national government lacked authority to deal with violations of the law of nations. As James Madison wrote, "these articles contain no provision for the case of offenses against the law of nations; and consequently leave it in the power of any indiscreet member to embroil the Confederacy with foreign nations." ${ }^{84}$ In May 1787, just before the start of the Philadelphia Convention, George Mason wrote that with regard to the courts " $[\mathrm{t}]$ he most prevalent idea [was] ... to establish ... a judiciary system with cognizance of all such matters as depend upon the law of nations, and such other objects as the local courts of

82. See Bradley, supra note 15.

83. See William S. Dodge, The Constitutionality of the Alien Tort Statute: Some Observations on Text and Context, 42 VA. J. INT'L L. 687, 701-11 (2002).

84. ThE FEDERALiST No. 42, at 265 (James Madison) (Clinton Rossiter ed., 1961). 
justice may be inadequate to." 85

Even if this did not represent the thinking of the entire Convention, it certainly reflected the views of the Virginia delegation, whose Virginia Plan would have extended the jurisdiction of the federal courts to "questions which may involve the national peace and harmony." 86 The alternative Pinckney Plan provided for a federal court to hear appeals from the states "in all Causes wherein Questions shall arise on the Construction of Treaties made by U.S.-or on the Law of Nations." 87 These plans, along with the New Jersey Plan, which made no mention of cases involving the law of nations, were referred to the Committee of Detail near the end of July. Although several of the Committee's drafts provided for jurisdiction over cases involving the law of nations, the draft reported to the Convention on August 6 limited arising-under jurisdiction to "cases arising under laws passed by the Legislature of the United States." 88 Had the text remained in this form, it would have been clear that Article III did not extend jurisdiction to cases arising under the law of nations. On August 27, however, the Convention voted to strike the words "passed by the Legislature." 89 This change in the text confirms what the comparison with Article VI suggests-that the phrase "Laws of the United States" in Article III was not limited to those laws passed by Congress.

During the ratification debates, advocates on both sides read Article III as allowing federal jurisdiction over cases involving the law of nations. John Jay wrote in Federalist No. 3:

Under the national government, treaties and the articles of treaties, as well as the laws of nations, will always be expounded in one sense and executed in the same manner-whereas adjudications on the same points and questions in thirteen states, or in three or four confederacies, will not always accord or be consistent. . . The wisdom of the convention in committing such questions to the jurisdiction and judgment of courts appointed by and responsible only to one national government cannot be too much commended. ${ }^{90}$

85. 3 THE RECORdS OF THE FEDERAL CONVENTION OF 1787, at 24 (Max Farrand ed., 1911) (reprinting letter from George Mason to Arthur Lee (May 21, 1787)).

86. Id. at 22 .

87. Id. at 608 .

88. Id. at 186 .

89. Id. at $423-24,431$.

90. THE FEDERALIST No. 3, at 41, 43 (John Jay) (Clinton Rossiter ed., 1961). Alexander Hamilton's Federalist No. 80 was more equivocal. On the one hand, he equated "the Laws of the United States" with "laws of the United States, passed in pursuance of their just and constitutional powers of legislation." THE FEDERALIST NO. 80, at 475 (Alexander Hamilton). On the other hand, he stated that "cases arising upon treaties and the law of nations ... may be 
Opponents of the new Constitution read Article III the same way. At the Virginia Convention, anti-federalist William Grayson complained: "There is to be one Supreme Court-for chancery, admiralty, common pleas, and exchequer, ... to which are added, criminal jurisdiction and all cases depending on the law of nations - a most extensive jurisdiction!"91 Significantly, none of the speakers who rose to defend the proposed Constitution disputed Grayson's assertion that the jurisdiction of the federal courts would extend to "all cases depending on the law of nations."

If the original understanding of Article III was that it allowed for federal jurisdiction over cases that involved the law of nations, do changes in the legal order since 1787 offer any reasons to modify that interpretation? One of the principal shifts over that period has been in the foundations of customary international law. In the eighteenth century, the law of nations was thought to rest primarily on principles of natural law, which courts could discover through the application of reason alone. Vattel wrote in his influential treatise that "the Law of Nations is in its origin merely the Law of Nature applied to Nations,", observed that "every doctrine, that may be fairly deduced by correct reasoning from the rights and duties of nations, and the nature of moral obligation, may theoretically be said to exist in the law of nations." Over the course of the nineteenth century, however, the conception of customary international law changed from natural law to positivism, so that judges no longer derived its rules by reasoning from first principles but instead looked to "the customs and usages of civilized nations," in other words to what states actually do in practice out of a sense of legal obligation. This shift naturally reduced the role of the judiciary in making customary international law, as it increased the role of the political branches.

One can see that many of the reasons for caution cited by the Sosa Court reflect this shift. The Court repeatedly stressed the desirability of

supposed proper for the federal jurisdiction." $I d$. at 476 .

91. The Virginia Convention (June 21, 1788) in 10 THE DOCUMENTARY HISTORY OF THE RATIFICATION OF THE CONSTITUTION 1445-46 (John P. Kaminski \& Gaspare J. Saladino eds., 1993). Grayson referred only to the Supreme Court because Article III did not require Congress to create lower federal courts.

92. E. DE Vattel, The Law of Nations or the Principles of Natural law APPLIED TO THE CONDUCT AND TO THE AFFAIRS OF NATIONS AND OF SOVEREIGNS, Intro. $§ 6$ (Charles G. Fenwick trans., 1916) (1758). For further discussion, see William S. Dodge, Withdrawing from Customary International Law: Some Lessons from History, 120 YALE L.J. ONLINE 169 (2010).

93. United States v. The La Jeune Eugenie, 26 F. Cas. 832, 846 (C.C.D. Mass. 1822).

94. The Paquete Habana, 175 U.S. 677, 700 (1900). 
"legislative guidance," "legislative judgment," and a "congressional mandate." 95 But these arguments apply with much less force to Article III than they did to the ATS for one very simple reason: the judicial power established by Article III is not self-vesting. Congress must pass a statute conferring some or all of this jurisdiction on the federal courts and Congress is under no obligation to give the federal courts all of the jurisdiction that Article III permits. Thus, even though Article III permits federal court jurisdiction over cases arising under customary international law, Congress must still authorize the federal courts to hear such cases. At the very least it must pass a statute granting jurisdiction, like the ATS, and under modern assumptions it must create an express cause of action as well. Thus, there is no need to fear that interpreting Article III to embrace customary international law will lead to unbridled involvement in foreign affairs by the federal courts.

The Sosa Court also mentioned as a reason for caution "the potential implications for the foreign relations of the United States." 96 In the context of Article III, those implications argue in favor of the original understanding that cases arising under customary international law are part of "the Laws of the United States." If Congress cannot give the federal courts jurisdiction over these cases, they will be left to the state courts, which may interpret customary international law in divergent ways and give offense to foreign nations. It was precisely to avoid such possibilities, Jay noted in Federalist No. 3, that the Constitution allowed the federal courts to hear cases involving the law of nations. Two centuries later, the Supreme Court still recognizes the "uniquely federal interests' ... [ [in] international disputes implicating ... our relations with other nations." In short, the original understanding of Article III as embracing cases arising under customary international law works as well today as it did at the Founding.

\section{Customary International Law and the States}

A final issue that the Supreme Court left open in Sosa is the relationship between customary international law and the states. If customary international law today or at some point in the future were to prohibit certain applications of the death penalty, for example, would the states have to obey that law? In Roper $v$. Simmons, the Supreme Court held that the Eighth Amendment prohibits the execution of those who

95. Sosa v. Alvarez-Machain, 542 U.S. 692, 726-28 (2004).

96. Id. at 727 .

97. Tex. Indus., Inc. v. Radcliff Materials, Inc., 451 U.S. 630, 640-41 (1981) (quoting Banco Nacional de Cuba v. Sabbatino, 376 U.S. 398, 426 (1964)). 
were under the age of eighteen when they committed their crimes. Controversially, in the course of its opinion, the Court looked to foreign practices for confirmation of its conclusion. ${ }^{98}$ Whether these foreign practices resulted from a sense of obligation and therefore reflect customary international law the Court did not make clear. If they did, however, incorporating these practices through the Supremacy Clause of Article VI offers an alternative-and perhaps a better one-to incorporating them through the Eighth Amendment.

The Supremacy Clause reads as follows:

This Constitution, and the Laws of the United States which shall be made in Pursuance thereof; and all Treaties made, or which shall be made, under the Authority of the United States, shall be the supreme Law of the Land; and the Judges in every State shall be bound thereby, any Thing in the Constitution or Laws of any State to the Contrary notwithstanding.

The text of this clause does not mention the law of nations. Moreover, in contrast to the unqualified phrase "Laws of the United States" in Article III, Article VI's limiting language "which shall be made in Pursuance [of this Constitution]" seems to exclude the law of nations. In the eighteenth century, the law of nations was not thought of as being made through internal processes of any nation, but primarily as an application of natural law. Moreover, the use of the future tense in this phrase would exclude the law of nations because that law long predated the Constitution. As Chief Justice John Jay stated in Chisholm v. Georgia, even before "the date of the Constitution . . . the United States had, by taking a place among the nations of the earth, become amenable to the laws of nations." 99

One might explain the omission by looking, as Sosa suggests, to "the ambient law of the era." 100 As general common law, the law of nations was considered binding upon the states already, and there would therefore have been no need to list it in the Supremacy Clause. As Professor Louis Henkin has explained, "[t]he law of nations of the time was not seen as something imposed on the states by the new U.S. government; it had been binding on and accepted by the states before the U.S. government was even established."101

98. 543 U.S. 551, 575-78 (2005); see also Graham v. Florida, 130 S. Ct. 2011, 2033-2034 (2010) (looking to foreign practice in holding that life without parole for juvenile offenders who did not commit homicide violates Eighth Amendment).

99. 2 U.S. (2 Dall.) 419,474 (1793).

100. Sosa v. Alvarez-Machain, 542 U.S. 692, 714 (2004).

101. Henkin, supra note 16, at 1566. 
Ware v. Hilton ${ }^{102}$ is sometimes said to reflect the understanding that states had authority to violate the law of nations through their own legislation. Ware involved a 1777 Virginia debt confiscation statute that was alleged to violate both the law of nations and the 1783 Treaty of Paris ending the Revolutionary War with Britain. With respect to the treaty, the Supreme Court held that the Supremacy Clause made it superior to Virginia's statute. With respect to the law of nations, however, those justices who addressed the question conceded that Virginia had the authority to violate it. Justice Samuel Chase wrote:

It is admitted, that Virginia could not confiscate private debts without a violation of the modern law of nations, yet if in fact, she has so done, the law is obligatory on all the citizens of Virginia, and on her Courts of Justice; and, in my opinion, on all the Courts of the United States.

Justice Iredell agreed: "admitting that the Legislature had not strictly a right, agreeably to the law of nations, to confiscate the debt in question; yet if they in fact did so, it would ... have been valid and obligatory within the limits of the States." 104

In fact, Ware does not support the proposition that states may violate the law of nations under the Constitution for the simple reason that the confiscation statute at issue was passed before the Constitution, or even the Articles of Confederation, came into effect. Virginia's position under the law of nations in 1777 was that of an independent nation, a point emphasized both by Chase and by Iredell. ${ }^{105}$ More reflective of the original understanding is Rutgers $v$. Waddington, a case argued by Alexander Hamilton and decided by the Mayor's Court of New York. ${ }^{106}$ In the spring of 1783 , New York-then part of the United

102. 3 U.S. (3 Dall.) 199 (1796).

103. Id. at 229 .

104. Id. at 265 .

105. See id. at 224 (Chase); id. at 266 (Iredell). Both Chase and Iredell also found it significant that the rule against confiscating debts was only a rule of "customary" law and not of "voluntary" law. See id at 227 (Chase); id. at 263 (Iredell). International law at the time distinguished between "customary" rules based on state practice that nations could opt out of (at least with proper notice), see VATTEL, supra note 92, Intro. §§ 25-26, and "voluntary" rules based on natural law to which nations were bound irrespective of their actual consent. See id., Intro. § 2l, Bk. III § 192. Indeed Chancellor George Wythe found the same Virginia statute invalid under the law of nations because he took the rule against confiscating debts to be based on natural law and not just custom. See Page v. Pendleton, Wythe's Rep. 211, 212 \& n.(b) (Va. Ch. 1793). For further discussion, see William S. Dodge, Customary International Law, Congress, and the Courts: Origins of the Later-in-Time Rule, in MAKING TRANSNATIONAL LAW WORK IN THE GLOBAL ECONOMY: ESSAYS IN HONOUR OF DETLEV VAGTS 531 (Pieter Bekker, Rudolf Dolzer \& Michael Waibel eds., 2010)

106. Both Hamilton's papers and the court's opinion are reprinted in 1 JULIUS GOEBEL, 
States under the Articles of Confederation-passed a Trespass Act to allow those whose property had been occupied by the British to sue for damages. Hamilton argued that the act was contrary to the law of nations, which no individual state had the authority to violate. The court avoided this question by construing the statute not to conflict with the law of nations, but it acknowledged that there was "very great force in the observation arising from the foederal compact." 107 The court reasoned that "to abrogate or alter any one of the known laws or usages of nations, by the authority of a single state, must be contrary to the very nature of the confederacy." 108

Even if the original understanding had been that the states were not bound by the law of nations, there are good reasons today to depart from that understanding. First, the Supreme Court has held that other sources of law not mentioned in Article VI are nevertheless supreme over state law. In United States v. Belmont, ${ }^{109}$ the Court held that executive agreements override inconsistent state law. After noting that the supremacy of treaties was established by the express language of Article VI, the Court reasoned that "the same rule would result in the case of all international compacts and agreements from the very fact that complete power over international affairs is in the national government and is not and cannot be subject to any curtailment or interference on the part of the several states." "The same reasoning applies equally to customary international law. Although its supremacy is not established by the express language of Article VI, it follows "from the very fact that complete power over international affairs is in the national government."

Second, "the potential implications for the foreign relations of the United States" 111 argue in favor of supremacy for customary international law. The Sosa Court observed that "[i]t is one thing for American courts to enforce constitutional limits on our own State and Federal Governments' power, but quite another to consider suits under rules that would go so far as to claim a limit on the power of foreign governments over their own citizens." 112 Nevertheless, the Court interpreted the ATS to allow suits against foreign officials for violations of customary international law. The quotation suggests that holding

JR., The Law PRactice of AleXander Hamilton: DoCuments and COMMENTARY 282419 (1964).

107. Id. at 405 .

108. ld. at 406.

109. 301 U.S. 324 (1937).

110. Id. at 331 .

111. Sosa v. Alvarez-Machain, 542 U.S. 692, 727 (2004).

112. Id. 
states to obey the obligations of customary international law would not raise similar foreign relations concerns. In fact, recent experience shows it is the failure of states to follow international law that may cause difficulties with other nations. State violations of the Vienna Convention on Consular Relations with respect to foreign nationals arrested for capital crimes have led other nations to sue the United States in the International Court of Justice (I.C.J.). ${ }^{113}$ One may expect a similarly hostile reaction from other nations if a state tried to execute a foreign national in violation of customary international law-the prohibition against executing pregnant women, for example.

Finally, binding the states to obcy customary international law under the Supremacy Clause would be less invasive of state sovereignty than what the Supreme Court is currently doing - using foreign practices to interpret the Eighth Amendment. Congress has no power to overturn the Supreme Court's interpretation of the Eighth Amendment. But it does have the power to violate customary international law and so could authorize states to engage in practices like the executing of pregnant women that would violate that law, even if customary international law were held to be binding under the Supremacy Clause.

Holding the states to the rules of customary international law under Article VI would thus fit with the proper allocation of authority over international affairs in the modern U.S. legal system. On the one hand, it would help ensure that states could not embroil the United States in disputes with other nations by violating customary international law. On the other hand, it would recognize that the final word on whether the United States will follow those rules properly rests with Congress rather than with the courts.

113. See Avena and Other Mexican Nationals (Mex. v. U.S.), 2004 I.C.J. 128 (Mar. 31); LaGrand (F.R.G. v. U.S.), 2001 I.C.J. 104 (June 27). In Medellin v. Texas, 128 S. Ct. 1346 (2008), the Supreme Court held that the I.C.J.'s judgment in Avena was not directly enforceable in American courts. Mexico filed a request for interpretation, and on July 16, 2008 the I.C.J. ordered the United States take all measures necessary to ensure that Medellin and four other Mexican nationals were not executed until they received the reconsideration required by the Avena. After Texas executed Medellin without providing such reconsideration, the I.C.J. found unanimously that the United States had breached its order of July 16. Request for Interpretation of the Judgment of 31 March 2004 in the Case Concerning Avena and Other Mexican Nationals (Mex. v. U.S.) (Jan. 19, 2009), available at http://www.icjcij.org/docket/files/139/14939.pdf. 


\section{CONCLUSION}

Sosa v. Alvarez-Machain stands both for continuity and for change. On the one hand, it strives hard to understand and to give effect to the views of the founding generation. It rejects the "avulsive" break with the past urged (ironically) by Justice Scalia, who would have read Erie to abolish by judicial fiat the notion that international law is part of the law of the land. " As the Court put it in response to Scalia, "it would be unreasonable to assume that the First Congress would have expected federal courts to lose all capacity to recognize enforceable international norms simply because the common law might lose some metaphysical cachet on the road to modern realism." 115 On the other hand, Sosa also tries to appreciate and to accommodate the enormous changes in international and domestic law that have occurred over the course of more than two centuries. It rejects blind originalism in favor of a more balanced and nuanced approach.

In my view, the Court got the balance right in Sosa. It held that federal courts may continue to hear claims under modern customary international law without expanding those claims beyond what the First Congress might reasonably have expected or beyond what the current division of responsibility for foreign affairs will reasonably allow. It held that customary international law constitutes federal common law in the post-Erie world without opening the floodgates to claims under the general federal question statute unless Congress passes express causes of action.

Of course, Sosa also leaves a host of questions unaddressed, and I have tried to suggest what some of the answers might be using Sosa's own approach. The original understanding was that the President was bound by customary international law under Article II of the Constitution, that the federal courts could be given jurisdiction over cases arising under customary international law under Article III, and that customary international law bound the states under Article VI.

In my view, the original understandings of Articles III and VI remain as persuasive today as they were in 1787 . Congress should have the option of letting the federal courts hear cases arising under customary

114. Sosa, 542 U.S. at 744 (Scalia, J., concurring).

115. Id. at 730 . 
international law so that such cases will not have to be left to the courts of several states. Nor should the states be free to violate customary international law, at least without the express authorization of Congress. Article II presents a closer question. While I accept the argument that the United States must be free to violate customary international law if it is to participate in the development of that law, I am not convinced that the President must have the authority to do this without congressional authorization.

In sum, Sosa v. Alvarez-Machain is a landmark decision charting the relationship between international and domestic law, a decision as significant as the Supreme Court's Sabbatino ${ }^{116}$ opinion forty years earlier. Like Sabbatino, Sosa is likely to be the subject of endless arguments about what it says and what it means. This is not because the opinion is unclear, but rather because it implicates a host of issues that stretch far beyond the specific question that the Court decided.

116. Banco Nacional de Cuba v. Sabbatino, 376 U.S. 398 (1964). 